\title{
Research on the Construction of Consumption Experience Dimensions for the E-Commerce Offline Store
}

\author{
Xianfeng Wu, Hanmeng Tan \\ School of Economics and Management, Chongqing University of Posts and Telecommunications, Chongqing, China \\ Email: 18883282718@163.com
}

How to cite this paper: Wu, X.F. and Tan, H.M. (2019) Research on the Construction of Consumption Experience Dimensions for the E-Commerce Offline Store. Open Journal of Social Sciences, 7, 408-417. https://doi.org/10.4236/jss.2019.73034

Received: March 6, 2019

Accepted: March 22, 2019

Published: March 25, 2019

Copyright $\odot 2019$ by author(s) and Scientific Research Publishing Inc. This work is licensed under the Creative Commons Attribution International License (CC BY 4.0).

http://creativecommons.org/licenses/by/4.0/

\begin{abstract}
Under the background of new retail, many E-commerce giants at home and abroad have started to open offline stores, and claimed to incorporate the consumption experience of offline stores into the superior future strategies. Based on the literature review and practical research methods, this paper explores the characteristics of this new E-commerce offline store which involves online and offline consumption experience features, and constructs the consumption experience dimensions belonging to the E-commerce offline store: sensory experience, emotion experience, service experience, convenience experience, interaction experience.
\end{abstract}

\section{Keywords}

E-Commerce Offline Store, New Retail, Consumption Experience

\section{Introduction}

The new retail was first proposed by Ma Yun, founder of Alibaba, at the Ali Yunqi Conference in 2016. He said that "the era of pure E-commerce will soon end. In the next ten or twenty years, there will be only 'new retail' where online and offline and logistics must be combined together". In fact, before the word was created, this phenomenon has already been revealed in the market: physical stores also have opened up online channels, and E-commerce companies have sought offline channels. The relationship between physical stores and E-commerce began to change from battling to merging.

JD announced that it will open a million of convenient stores in five years and five thousand maternal and child experience stores in the next three years; Xiaomi declared that 1000 Xiaomi homes in the next three years will be 
founded, 228 already have been laid at the end of 2017. Amazon has opened a 1800-square-foot AMAZON GO self-service supermarket in Seattle; Alibaba's popular Hema stores ... The reasons behind these market behaviors: one is that E-commerce has got some problems on how to increase more online traffic, one report from Zhiyan consulting agency [1] shows that Jingdong Mall received customer costs in 2012 for 65.30 yuan/person, it reached 226.10 yuan/person in 2017, with a 5 -year compound growth rate of $28.20 \%$; the cost of Alibaba's acquisition of an active new user increased from 50.89 yuan in 2013 to 226.58 yuan in 2017; the growth rate is nearly 3.5 times through just 4 years. Another reason is with the better living quality level and skilled experience in multi-channel shopping, customers no longer only pay attention to the price, but put forward higher requirements for experience, quality and brand. The advantages of the physical store's, such as experience trial, transaction security, timely pick-up, and face-to-face interaction can meet these demands [2].

Previous studies have just focused on the review of new retail meanings, models or development strategies roughly, rarely focusing on the specific object: the E-commerce offline store, moreover explored it from the perspective of consumption experience. This article will stand the view of consumption experience to research E-commerce offline store which has both the offline and the online features. The structure of E-commerce offline store's consumption experience will be given through these efforts.

\section{Concepts Related to E-Commerce Offline Store}

The generation of the E-commerce offline store can reflect the rise of new retail idea, and this market is different and the demand for consumption experience has changed too. Before doing further research on the E-commerce offline store, we should have a deep understanding of the two concepts it involves: new retail and consumption experiences.

\subsection{New Retail}

The theoretical base of the new retail is the wheel of retailing theory which is created by McNair's [3]. The main content of this theory is that the development of cheap sales as a competitive advantage is bound to transform into a high-price, high-cost, high-gross profit retail trend, while at the same time, there will be new enterprises with low cost, low gross profit and low price enter the market, and the wheel of retailing begins to turn again. According to this theory, a new retail organization or form will go through three stages: entry, cost increase, and decline. The motivation for the development of new retail is because the E-commerce pattern has shown signs of decline now. Research on new retail is in its infancy, and everyone has different perceptions of its meaning. Zhao Shumei and Xu Xiaohong [4] believe that the new retail is the total activities about adopting cutting-edge idea and advanced Internet technology, improving and innovating the traditional retail, using the latest thought as a guide 
to sell goods or services to consumers. Wang Baoyi [5] points out that the essence of new retail is the comprehensive retail format that better meets the consumers' needs of shopping, socializing and entertaining with the omni-channel and pan-retail mode in the era of data-driven and consumption upgrade. The new retail reflects the trend of the market shifting from product-oriented took consumer-oriented. Under this guidance, how to promote product quality, consumption experience, and personalized consumption become the main appeal, every activity the company carries out should benefit the "customers are supreme" environment atmosphere [6]. In this paper, new retail is defined as the mixed form of physical retailer and high-tech digital application to help consumers' shopping experience in all aspects.

\subsection{Consumption Experience}

Although there is no clear definition of consumption experience in the academic field, the following research conclusions and understanding about it are widely recognized and cited. In "The Experience Economy", Joseph Pine and James H. Gilmore [7] point out that the consumption experience is a positive feeling of inner pleasure when an individual voluntarily participates and enters the enterprise's activities whole heartedly. It is a kind of beautiful feeling when a person reaches a certain physical, emotional and mental level. In "Experiential Marketing", when Bernd H. Schmitt [8], answers the question "What is the experience?", the experience is defined as the internal response to certain stimulation, related to the entire human body. And he also explains that experience is a very complicated thing, always retaining novelty, there are no two same experiences in the world. Another widely accepted view is Csikszentmihalyi's flow experience [9], he defines the flow experience as the overall feeling of the individual entering a certain activity completely. When the individual is in the state of flow experience, they are completely deep in what they are doing.

The construct of consumption experience dimension also is different from one to one. It can be divided into four dimensions according to the individual participation mode and the degree of immersion in the experience process: educational experience, escaping reality experience, aesthetic experience, and entertainment experience [7]. In the past, consumers' shopping behavior was a rational decision considering elements such as product and price. Now they pay more attention to the feeling and the consumption process is an irrational behavior. The consumption experience requires 3Fs [10]: Feeling, Fantasy, Fun. Later on this, the 4Es [11] is proposed: Entertainment, Exhibitionism, Experience, Evangelizing, which covers these four major components and 12 types. According to the theory of flow experience [9], the nine consumption experience dimensions are also divided: perception of clear goals, immediate feedback, matching of personal skills and task challenges, integration of behavior and perception, concentration of attention, potential control feelings, loss of self-awareness, change in the sense of time and an aimed experience. Bernd $\mathrm{H}$. 
Schmitt [8] proposes five kinds of experience dimensions from the perspective of psychology: sense, feel, think, act, relate.

\section{E-Commerce Offline Store Concept Definition}

The E-commerce offline store referred the category that meets the characteristics of "new retail": it requires online and offline linkage, and has innovative technologies such as big data, cloud computing, and epc system network. This type of E-commerce offline store is one of the first modes of E-commerce channels with experience-based consumption sinking, the core is the consumption experience.

So what are the differences between this E-commerce offline store and traditional offline store and experiential store? The main purpose of traditional offline store is to sell goods, and the main pursuit of E-commerce offline store is to gain the growth of other assets by giving consumers a better experience. This has led to different attitudes in the decoration. Most of the E-commerce offline stores are located in the business district, and the stores floor area are not small, indoor decoration and design are with more personality and art feeling; at the same time, the service also reduces the orientation of persuasion, and no longer follows the peddling service. The E-commerce store relies on the huge database and excellent technical capabilities accumulated by E-commerce companies for many years, making it even easier in terms of convenience and interaction. For example, Amazon's AMAZON GO offline self-service supermarket can judge the most common shopping path for consumers according to the motion recognition technology, and then change the shelf position and product display to facilitate consumers. What is more, the application of technologies such as radio frequency technology which indicates the electromagnetic frequency that can be radiated into space, ranging from $300 \mathrm{KHz}$ to $300 \mathrm{GHz}$, face recognition and virtual reality technology that is a computer simulation system that can create and experience virtual worlds can better meet the fast payment that consumers expect, that is, take away as fast as they can. Although the experiential store is as focused on the consumer experience as the E-commerce offline store, the experiential store has not been given too many functions and scene imagination due to the immature technology and lack of data, more of the display and trial functions. In the experiential store, there is no comprehensive and systematic design of consumption experience like the E-commerce offline store.

\section{Offline \& Online Consumption Experience Dimensions}

Regarding the consumption experience dimensions of E-commerce offline store, no answer has been given to this question for now. This study can only summarize the relative consumption experience dimensions of offline stores and E-commerce. Finally, according to the degree of integration of E-commerce offline store, the consumption experience dimensions belonging to it is constructed. 


\subsection{Offline Consumption Experience Dimensions}

Consumption experience researches actually originated from the offline, mostly based on physical stores. For example, Jones's [12] research divides the store experience dimensions into store factors including product selection, commodity prices, service personnel, and customer factors including social impact, experience, product preferences, etc. Ibrahim and Wee [13] emphasize the important influence of traffic factors on the consumption experience; Terblanche and Boshoff [14] have done a series of researches on the store shopping experience, they believe that the consumption experience is all the experience and contact between the customer from arriving the physical store to leaving, propose In-Store-Experience (ISE) model, which includes five factors: personnel contact, personal interaction, merchandise value, store environment, merchandise variety and assortment, and compliant handling; Tian Shengbing's [15] conclusion about offline store consumption experience dimensions includes store shopping environment experience, store personnel service experience, product experience, after-sales service experience; Pa Xia Ning and Zhang Liyun [16] give physical store operation advice from sensory experience, service experience, emotional experience, and communication experience; Joseph [17] studies between person-to-person experience, store shopping experience, price and value, data integration and analytics, marketing and communications impact on offline store consumption experience; Zhang Zhenxing and Bian Yajing [18] divide the experience into sensory experience, emotional experience, thinking experience, relationship experience, and moral experience through literature induction. All the offline consumption experience dimensions which are mentioned above are summarized in Table 1.

\subsection{Online Consumption Experience Dimensions}

In the online consumption experience dimension studies, Davenport [20] believes that compared with the physical environment directly acting on the senses, the online experience uses the interface instead of the direct experience in the real environment. Efthymios Constantinides [21] divides the online consumption experience into functional experience and psychological experience, content experience, which includes the study of website usability, interactivity, trust, aesthetics and marketing mix. Cao Mei and others [22] find that the website's fun experience and entertainment experience are one of the main indicators that influence consumption experience on the website. Mary Wolfinbarger and Mary C. Gilly [23] believe that some online shopping consumers will consider the convenience experience, selective experience, information usability experience, and free experience when they measure the consumption experience. Luo Gusong [24] divides the experience into five levels according to the effectiveness of E-commerce websites to help consumers achieve their goals: functional experience, mainly describes whether E-commerce websites can help users achieve their goals; the technical experience, describing whether an E-commerce site can 
help users achieve their goals efficiently; the aesthetic experience describes whether an E-commerce site enables users to achieve their goals with pleasure; the information experience, this describes online platform has the ability to make the attributes that the user achieves the goal, including the richness, comprehensiveness, and authenticity of the information; the process experience describes how does the E-commerce online platform enable users to achieve their goals, simplicity, convenience, and security are all involved in the process experience. Within the scope; Guo Guoqing [25], He Aizhong [26] borrow Bernd's consumption experience dimensions and examine the impact of the online platform's sensory experience, emotional experience, action experience, thinking experience, and connected experience. All the online consumption experience dimensions which are mentioned above are summarized in Table 2.

Table 1. Offline consumption experience dimensions.

\begin{tabular}{|c|c|}
\hline Authors & Offline consumption experience dimensions \\
\hline Kerin [19] & $\begin{array}{l}\text { Policy experience, shopping environment experience, } \\
\text { personnel service experience }\end{array}$ \\
\hline Jones & $\begin{array}{l}\text { Product selection, commodity prices, service personnel, and customer factors } \\
\text { including social impact, experience, product preferences, etc. }\end{array}$ \\
\hline $\begin{array}{l}\text { Wee \& } \\
\text { Ibrahim }\end{array}$ & $\begin{array}{l}\text { Shopping tendency (consumer factor), environmental atmosphere, shopping } \\
\text { center features, product quality and added value (business factors), shopping } \\
\text { mall convenience (traffic factors) }\end{array}$ \\
\hline $\begin{array}{l}\text { Terblanche } \\
\text { \& Boshoff }\end{array}$ & $\begin{array}{l}\text { Personnel contact, personal interaction, merchandise value, store environment, } \\
\text { merchandise variety and assortment, and compliant handling }\end{array}$ \\
\hline Tian Shengbing & $\begin{array}{l}\text { Shopping environment experience, store personnel service experience, product } \\
\text { experience, after-sales service experience }\end{array}$ \\
\hline $\begin{array}{l}\text { Pa Xia Ning } \\
\text { \& Zhang Liyun }\end{array}$ & $\begin{array}{l}\text { Sensory experience, service experience, emotional experience, and } \\
\text { communication experience }\end{array}$ \\
\hline Joseph & $\begin{array}{l}\text { Person-to-person experience, store shopping experience, price and value, data } \\
\text { integration and analytics, marketing and communications }\end{array}$ \\
\hline $\begin{array}{l}\text { Zhang Zhenxing } \\
\text { \& Bian Yajing }\end{array}$ & $\begin{array}{l}\text { Sensory experience, emotional experience, thinking experience, relationship } \\
\text { experience, moral experience }\end{array}$ \\
\hline
\end{tabular}

Table 2. Online consumption experience dimensions.

\begin{tabular}{|c|c|}
\hline Authors & Online consumption experience dimensions \\
\hline $\begin{array}{l}\text { Peter \& } \\
\text { Efthymios }\end{array}$ & $\begin{array}{l}\text { Functional experience and psychological experience, } \\
\text { content experience }\end{array}$ \\
\hline Cao Mei & Fun experience and entertainment experience \\
\hline \multicolumn{2}{|c|}{ Mary Wolfinbarger Convenience experience, selective experience, } \\
\hline \& Mary C. Gilly & information usability experience, and free experience \\
\hline Luo Gusong & $\begin{array}{l}\text { Functional experience, technical experience, } \\
\text { aesthetic experience, information experience, process experience }\end{array}$ \\
\hline Guo Guoqing, & Sensory experience, emotional experience, action experience, \\
\hline \& He Aizhong & thinking experience, and connected experience \\
\hline
\end{tabular}


We can find out from the online and offline dimensions of consumption experience that although both are from the perspective of consumers, the roots of the offline dimension are still built around physical stores, the online dimension is mainly around information technology to divergence. They are excited by different ontology.

\section{E-Commerce Offline Store Consumption Experience Dimensions Construction}

After a comprehensive and in-depth understanding of related concepts and online and offline consumption experience dimensions research, combined with the field visit research on E-commerce offline stores, this paper puts forward these dimensions that E-commerce offline store consumption experience should include.

\subsection{Sensory Experience}

People are particularly sensitive to five senses (vision, hearing, smell, taste, touch). According to the observation of the results of consumption experience researches, sensory experience is a very important part both of the online and offline consumption experience. The sensory experience of the online platform is mainly reflected in whether the web page design is simple and beautiful, whether it can bring the aesthetic experience to the consumer; the sensory experience of the offline store includes a series of feelings such as hearing and smell. Therefore, this study incorporates the sensory experience into the E-commerce store experience dimensions. It is not only theoretically reliable. In fact, in the field research of existing E-commerce offline stores, all the offline stores make great effort to show they are concerned about whether they can give consumers bring a good sensory experience.

\subsection{Emotion Experience}

Emotion experience is a very comprehensive and irrational experience. It is impossible to tell which aspect can affect the consumer's emotion experience exclusively. It is the experience feedback that brings together various elements. Consumers will have positive emotions for products and services, and even for brands in a comfortable and relaxed atmosphere. Incorporating emotion experience into the E-commerce offline store consumption experience dimensions can better measure the overall experience in the actual shopping and browsing process, and will play a direct role in the future management and strategy formulation of the enterprise.

\subsection{Service Experience}

The service experience here refers to the personnel service experience only, and the service experience of the E-commerce offline store is so heterogeneous that should be proposed particularly in the consumption experience dimensions. The demand of the contemporary consumer for the service personnel is to provide 
good, fast and professional services when the service is needed. More importantly, when the service is not needed, the service personnel can actively give back to the consumer to leave a comfortable personal space without bothering and selling information, so consumers can better devote themselves to the consumption process.

\subsection{Convenience Experience}

The E-commerce offline store is a new thing that comes in line with the new retail environment. It can use big data, artificial intelligence, cloud computing to quickly match user needs and achieve personalized marketing. The E-commerce offline store convenience experience applies the online technical experience and online traditional convenience experience into the offline store. The convenient experience here describes whether consumers can use high-tech products and advanced technology in the E-commerce offline store to help consumers save time, energy, and physical costs in search, comparison, payment, and browsing.

\subsection{Interaction Experience}

The interaction experience is the consumption experience brought by the interaction between E-commerce platform information and offline store information systems. We are in an era when mobile terminal technology is so developed, E-commerce companies should recognize the good interactions online and offline plays an important role in the store experience. The content of the interaction experience may be an extension of the information that offline (online) store already afford but not enough for consumers, they can get extra information online (offline), or it may complement the offline or online information which the other side completely lack.

\section{Conclusions}

This paper finally constructs the E-commerce offline store consumption experience structure with sensory experience, emotion experience, service experience, convenience experience and interaction experience as the sub-dimensions. In the future, it provides evidence for the research of the E-commerce store based on consumption experience view. It also gives ideas for the E-commerce companies to create a complete ideal consumption experience for consumers as the guiding role.

Since the E-commerce offline store itself and researches about it are both in its infancy, the construction of the dimensions cannot cover all the features of the e-commerce offline store 100 percentage. This is the major shortcoming of this paper. Moreover, features of E-commerce offline store are still in constant and rapid changes, and this change can also be used as one of the starting points for future research.

\section{Conflicts of Interest}

The authors declare no conflicts of interest regarding the publication of this paper. 


\section{References}

[1] Zhiyan Consulting Network (2018) Report on the Competitive Landscape and Future Trends of China's Online Shopping Industry in 2018-2024. https://www.chyxx.com/research/201805/636238.html

[2] Hsiao, M.-H. (2009) Shopping Mode Choice: Physical Store Shopping versus E-Shopping. Transportation Research Part E: Logistics and Transportation Review, 45, 86-95. https://doi.org/10.1016/j.tre.2008.06.002

[3] McNair, M.P. (1958) Signification Trends and Development in the Post-War Period. University of Pittsburgh Press, Pittsburgh, 18.

[4] Zhao, S.M. and Xu, X.H. (2017) The Meaning, Mode and Development Path of New Retail. China Circulation Economy, 31, 12-20.

[5] Wang, B.Y. (2017) Research on the Essence, Causes and Practice Trends of "New Retail”. China Circulation Economy, 31, 3-11.

[6] Liang, Y.Y. (2017) Research on the Emergence and Development of "New Retailing" in China Based on the Theory of "The New Retailing Wheel". Contemporary Economic Management, 39, 6-11.

[7] Pine, B.J. and Gilmore, J.H. (1999) The Experience Economy: Work Is Theatre and Every Business a Stage. Harvard Business School Press, Boston, 23-39.

[8] Schmitt, B.H. (1999) Experiential Marketing. Journal of Marketing Management, 15, 53-67. https://doi.org/10.1362/026725799784870496

[9] Csikszentmihalyi, M. (1993) Activity and Happiness. Journal of Occupational Science, 1, 38-42. https://doi.org/10.1080/14427591.1993.9686377

[10] Holbrook, M.B. and Hirschman, E.C. (1985) The Experiential Aspects of Consumption: Consumer Fantasies Feelings and Fun. Journal of Consumer Research, 5, 132-140.

[11] Holbrook, M.B. (2000) The Millennial Consumer in the Texts of Our Times: Experience and Entertainment. Journal of Macro Marketing, 20, 178-192. https://doi.org/10.1177/0276146700202008

[12] Jones, M. (1999) Entertaining Shopping Experiences: An Exploratory Investigation. Journal of Retailing and Consumer Services, 6, 129-139. https://doi.org/10.1016/S0969-6989(98)00028-9

[13] Muhammad, F.I. and Ng, C. (2002) The Importance of Entertainment in the Shopping Center Experience: Evidence from Singapore. Journal of Real Estate Portfolio Management, 8, 239-254.

[14] Terblanche, N.S. and Boshoff, C. (2006) The Relationship between a Satisfactory In-Store Shopping Experience and Retailer Loyalty. South African Journal of Business Management, 37, 33-43.

[15] Tian, S.B., Deng, N.Q. and Liu, Y.Z. (2017) The Impact of Department Stores Service Experience on Customer Loyalty. Journal of Shanghai University of International Business and Economics, 24, 34-44.

[16] Dang, X.N. and Zhang, L. (2010) Practical Application and Deep Thinking of Experiential Marketing Model. Commercial Times, No. 22, 29-30.

[17] Gagnon, J.L. (2002) Marking CRM Work for Retailing Survey. IBM Institute for Business Value No. 4, 1-3.

[18] Zhang, Z.X. and Bian, Y.J. (2011) Brand Experience, Concept, Dimension and Scale Construction. Statistics \& Decision, No. 10, 177-179.

[19] Kerin, R.A., Jain, A. and Howard, D.J. (1992) Store Shopping Experience and 
Consumer Price-Quality-Value Perceptions. Journal of Retailing, 68, 376-397.

[20] Davenport, T. and Beck, J. (2002) The Attention Economy: Understanding the New Currency of Business. Harvard Business School Press, New York.

[21] Constantinides, E. and Geurts, P. (2005) The Impacts of Web Experience on Virtual Buying Behavior: An Empirical Study. Journal of Customer Behavior, 4, 307-336. https://doi.org/10.1362/147539205775181249

[22] Cao, M., Zhang, Q. and Seydel, J. (2005) B2C E-Commerce Web Site Quality: An Empirical Examination. Industrial Management \& Data Systems, 105, 645-661. https://doi.org/10.1108/02635570510600000

[23] Wolfinbarger, M. and Gilly, M.C. (2001) Shopping Online for Freedom, Control, and Fun. California Management Review, 43, 34-55. https://doi.org/10.2307/41166074

[24] Luo, G.S. (2011) Comprehensive Evaluation of B2C E-Commerce Website Service Quality Based on User Experience. Shopping Modernization, No. 1, 100-102.

[25] Guo, G.Q., Zhou, J.M. and Yao, Y.N. (2013) Study on the Impact of Website Experience Marketing on Website Brand Image and User Experience Value. Clinical and Management Review, 29, 58-65.

[26] He, A.Z. and Gong, W. (2010) Empirical Research on the Influence of E-Shopping Experience upon Customer Behavioral Intention. Journal of Beijing Technology and Business University, 25, 43-47. 